\title{
Acute toxicity study of Phyllanthus niruri and its effect on the cyto-architectural structure of nephrocytes in Swiss albino mice Mus-musculus
}

\author{
Tanuja Singh', Ruchi' ${ }^{2}$ Anjali Singh ${ }^{3}$, Ravish Kumar ${ }^{3}$ and Jitendra Kumar Singh ${ }^{4}$ \\ 'Department of Botany, Thakur Prasad Singh, College, Magadh University, Patna. \\ 2Department of Botany, Braj Mohan Das College, Dayalpur, Babasaheb Bhimrao Ambedkar, Bihar University, Bihar, India-844502. \\ ${ }^{3}$ Research Centre, Mahavir Cancer Sansthan, Phulwarisharif, Patna, India. \\ ${ }^{4}$ Department of Research, S.S. Hospital and Research Institute, Patna, India.
}

\begin{abstract}
Background: In the era of herbal renaissance, world is moving towards the medicinal plant that repairs and strengthening the body system without any toxic side effects. Popular medicinal plant Phyllanthus niruri contains various bioactive molecules, the present study aimed to observe the biochemical and cyto-architectural alterations in kidney associated with acute oral toxicity $\left(\mathrm{LD}_{50}\right.$ ) of aqueous extract of P.niruri in Swiss albino mice. However, limited data is available about the toxicity of herbal remedies used for medication, which is a critical constrain. Materials and Methods: For the acute oral toxicity study, the animals were divided into six groups of 6 mice each. Group-I was named control group and the treatment groups were administered aqueous leaf extract of P.niruri orally at different doses of $500 \mathrm{mg} / \mathrm{Kg} \mathrm{bw}$ (Group-II), $1000 \mathrm{mg} / \mathrm{Kg}$ bw (Group-III), $2000 \mathrm{mg} / \mathrm{Kg}$ bw (Group-IV), $2500 \mathrm{mg} / \mathrm{Kg} \mathrm{bw}$ (Group-V) and $3000 \mathrm{mg} / \mathrm{Kg}$ bw (Group-VI) for 7 consecutive days. The mice were sacrificed on and serum was collected for the biochemical analysis. The kidney was dissected and processed for histological analysis. Results: The $L_{50}$ dose of $P$. niruri was found to be $2590.984 \mathrm{mg} / \mathrm{Kg}$ bw in Swiss albino mice model in labo-
\end{abstract}

ratory condition. The result showed the elevated serum level of urea in treated group of mice at higher doses which was found to be statistically significant as compared to the control (Group-I). There were no any significant increase in serum creatinine has been observed. Histological alteration were observed at higher dose more than $2500 \mathrm{mg} / \mathrm{Kg}$ bw (Group-VI). Conclusion: It is evident from our study that $P$. niruri may have toxic effect at high doses. Therefore, it should be ingested with precautions.

Key words: P. niruri, LD $_{50}$, Kidney, Biochemical, Histological analysis.

Address for Correspondence:

Dr. Tanuja Singh, Department of Botany, Thakur Prasad Singh College, Patna, Magadh University, Bihar, India.

Phone no:- +91- 9835412997/7352126582

E-mail: tanujasinghtps@gmail.com

DOI : 10.5530/pj.2016.1.17

\section{INTRODUCTION}

In the era of herbal renaissance, the demand for medicinal plant is increasing globally in both developed and developing countries. The world is now moving towards the medicinal plant that repairs and strengthening the body system without any toxic side effects. ${ }^{1}$ Recently, scientific interest in medicinal plants has burgeoned due to the increased efficiency of plant derived drugs and raising concern about the side effects of modern medicine and resistant to the drugs. Impressive number of modern drugs has been isolated from natural sources, is being used as traditional medicine. As a result, plant based traditional medicine continues to play an essential role in health care, with $80 \%$ of the world's inhabitants relying mainly on traditional medicines for their primary health care. ${ }^{2}$ According to World health organization, about three quarters of the world's population currently use traditional medicine. Traditional medicine is an important part of Indian culture and herbs are now very popular in developing countries on account of their improved knowledge about their safety, efficacy, and quality assurance of ethno medicine. In recent years, secondary plant metabolites (phytochemicals) have been extensively investigated as a source of medicinal agents. ${ }^{3}$ Therefore, in order to have standard natural plant products, preliminary studies have to be conducted in order to evaluate possible risks such as, undesirable effects, overdose or poisoning. ${ }^{4}$ In the Phyllanthaceae family one of the common herb that is widely used is P.niruri and proven therapeutic effects. ${ }^{5}$ This species is indigenous to S. America, India, and China, widely distributed in many tropical countries where they are considered as weeds. The whole plant is used as a remedy for many conditions such as tumours, diabetes, diuretics, jaundice, kidney stone and dyspepsia etc. The plant is also useful for treating hepatotoxicity, hepatitis B and hyperglycaemia, viral and bacterial diseases. ${ }^{6,7}$ Curative properties of the medicinal plant are due to the presence of bioactive phytochemicals, among which polyphenols are the most numerous and widely distributed class of phytochemicals. Polyphenols include classes of chromones, coumarins, lignans, stilbenes, xanthones and flavonoids. ${ }^{8}$ Flavonoids had been found to possess relatively potent antioxidant, anti-atherosclerotic, anti-inflammatory, anti-mutagenic, anti-tumor and anti-viral activities. ${ }^{9}$ Despite wide spread use of P.niruri for treating various diseases, mainly it is known as a potent stone breaker. Therefore, this study aimed to observe the biochemical, haematological and histological alterations in kidney associated with acute oral toxicity $\left(\mathrm{LD}_{50}\right)$ of aqueous leaf extract of $P$. niruri in Swiss albino mice. However, there is limited data available regarding its toxicity.

\section{MATERIALS AND METHODS}

\section{Experimental Animal}

Healthy Swiss albino mice, weighing between 30-35 g were obtained from a random-bred colony at the Mahavir Cancer Sansthan, Patna, Bihar, India. They were maintained under the optimal condition at the temperature- $\left(24 \pm 1^{\circ} \mathrm{C}\right)$, humidity- $(55 \pm 5 \%)$, and lighting- (12-h light/ dark cycle). Food and distilled water were given ad libitum throughout the study. Study were carried out as per CPCSEA guidelines (Approval No.-1129/bc/07/CPCSEA). 


\section{Collection and Identification of Plant Materials}

Leaf of P.niruri was collected from the campus of B.M.D College, Vaishali, taxonomically identified by Dr. S. Bedi, (Associate Professor, Department of Botany, PWC, Patna University, Patna). It is kept in the herbarium of the laboratory under the voucher specimen number: B.M.D/ $\mathrm{BOT} / 08 / 10$. The leaves were shade dried at room temperature $\left(25^{\circ} \mathrm{C}\right)$ for 10 days, powdered and stored.

\section{Acute Toxicity Study}

After acclimatization, the animals were divided into 6 groups of 6 mice each. The control (group-I) received food and distilled water ad libitum, while the experimental groups in addition received aqueous leaf extract of P.niruri orally at different doses of $500 \mathrm{mg} / \mathrm{Kg}$ bw(Group-II), 1000 $\mathrm{mg} / \mathrm{Kg}$ bw (Group-III), $2000 \mathrm{mg} / \mathrm{Kg}$ bw (Group-IV), $2500 \mathrm{mg} / \mathrm{Kg}$ bw (Group-V) and $3000 \mathrm{mg} / \mathrm{Kg}$ bw (Group-VI). The extract was prepared by dissolving $500 \mathrm{mg}-3000 \mathrm{mg}$ of dried powder of P.niruri leaves in 10 $\mathrm{ml}$ of distilled water. The volume of aqueous extract to be administered was determined based on body weight and given to the mice for 7 consecutive days. The toxicological effects were observed in terms of mortality expressed as $\mathrm{LD}_{50}$. Based on the experimental observations, the acute oral $\mathrm{LD}_{50}$ of the extract was calculated by the use of software for probit analysis (Environmental Protection Agency PROBIT ANALYSIS PROGRAM, used for calculating LC/EC value, Version 1.5).

\section{Biochemical Parameters Analysis}

The serum was obtained by centrifugation (3000 rpm for $15 \mathrm{~min}$ utes). Urea and creatinine levels was determined by the use of standard kit method using fully Automated Biochemistry Analyzer (Model No-SELECTRA-"E”,VITALAB BY MERCK) in the Biochemistry Department of Mahavir Cancer Sansthan and Research Centre, Patna.

\section{Histological Examination}

Mice were sacrificed by cervical dislocation and kidneys were extracted out, washed thoroughly in normal saline, fixed in $10 \%$ formal saline, trimmed, processed, embedded in paraffin wax, sectioned at a thickness of 4-5 $\mu \mathrm{m}$, stained by double staining method (H\&E) and observed under light microscope for histological changes.

\section{Statistical Analysis}

Data was analyzed and experimental values ware expressed as the mean \pm SEM and $P$ value was calculated using one way analysis of variance (ANOVA) by using SPSS software. $P \leq 0.05$ was considered statistically significant.

\section{RESULTS}

Swiss albino mice treated orally with different doses $(500 \mathrm{mg} / \mathrm{Kg}$ bw, $1000 \mathrm{mg} / \mathrm{Kg}$ bw, $2000 \mathrm{mg} / \mathrm{Kg}$ bw, $2500 \mathrm{mg} / \mathrm{Kg}$ bw, $3000 \mathrm{mg} / \mathrm{Kg}$ bw of aqueous leaf extract of $P$. niruri. The median acute toxicity $\left(\mathrm{LD}_{50}\right)$ of the compound was determined to be $2590.984 \mathrm{mg} / \mathrm{Kg}$ bw as per the observations using software of probit analysis (EPA PROBIT ANALYSIS PROGRAM, used for calculating LC/EC value, Version 1.5) as shown in Table 1. Results showed decrease in body weight in treated groups which was statistically significant $(P \leq 0.05)$ in Group-V and statistically very significant $(P \leq 0.01)$ in Group-VI as compared to Group-I (Table 2$)$. Relative kidney weight (K:BW) was also decreased which was statistically very significant $(P \leq 0.01)$ at higher doses (Group-V and Group-VI).

The biochemical parameters which reflect the functioning of kidney are level of urea and creatinine (Figure 1a, 1b). In the present investigation, it was recorded that the serum urea level in treated Group-II and Group-III increased but it was not statistically significant $(P \geq 0.05)$. However, treatment at higher doses of aqueous leaf extract of P.niruri
Table 1: Estimation of $\mathbf{L D}_{50}$

\begin{tabular}{cccccc}
\hline $\begin{array}{c}\text { Concentration } \\
\text { of aqueous } \\
\text { extract }\end{array}$ & $\begin{array}{c}\text { Number } \\
\text { exposed }\end{array}$ & $\begin{array}{c}\text { Number } \\
\text { responding }\end{array}$ & $\begin{array}{c}\text { Observed } \\
\text { proportion } \\
\text { responding }\end{array}$ & $\begin{array}{c}\text { Proportion } \\
\text { responding } \\
\text { adjusted for } \\
\text { controls }\end{array}$ & $\begin{array}{c}\text { Predicted } \\
\text { proportion } \\
\text { responding }\end{array}$ \\
\hline $\mathbf{5 0 0 . 0 0 0}$ & 6 & 0 & 0.0000 & 0.0000 & 0.0000 \\
$\mathbf{1 0 0 0 . 0 0 0}$ & 6 & 0 & 0.0000 & 0.0000 & 0.0005 \\
$\mathbf{2 0 0 0 . 0 0 0}$ & 6 & 1 & 0.1667 & 0.1667 & 0.1841 \\
$\mathbf{2 5 0 0 . 0 0 0}$ & 6 & 3 & 0.5000 & 0.5000 & 0.4506 \\
$\mathbf{3 0 0 0 . 0 0 0}$ & 6 & 4 & 0.6667 & 0.6667 & 0.6947 \\
\hline
\end{tabular}

Estimated LC/EC 50.0 of aqueous leaf extract of $P$. niruri was 2590.984 .

Table 2: Effect of aqueous leaf extract of P.niruri for seven days exposure period

\begin{tabular}{lcccccc}
$\begin{array}{l}\text { Weight } \\
\text { (gram) }\end{array}$ & $\begin{array}{c}\text { Group-I } \\
\text { (Control) }\end{array}$ & $\begin{array}{c}\text { Group-II } \\
(500 \mathrm{mg} / \\
\mathrm{Kg})\end{array}$ & $\begin{array}{c}\text { Group-III } \\
(1000 \mathrm{mg} / \\
\mathrm{Kg})\end{array}$ & $\begin{array}{c}\text { Group-IV } \\
(2000 \mathrm{mg} / \\
\mathrm{Kg})\end{array}$ & $\begin{array}{c}\text { Group-V } \\
(2500 \mathrm{mg} / \\
\mathrm{Kg})\end{array}$ & $\begin{array}{c}\text { Group-VI } \\
(3000 \mathrm{mg} / \\
\mathrm{Kg})\end{array}$ \\
\hline $\begin{array}{c}\text { Body wt. } \\
\text { before } \\
\text { dose }\end{array}$ & $30.12 \pm 0.22$ & $30.05 \pm 0.28$ & $30.10 \pm 0.22$ & $30.13 \pm 0.17$ & $30.12 \pm 0.19$ & $30.09 \pm 0.22$ \\
$\begin{array}{l}\text { Body wt. } \\
\text { after dose }\end{array}$ & $30.65 \pm 0.12$ & $30.14 \pm 0.23$ & $30.17 \pm 0.18$ & $27.43 \pm 0.33^{*} 26.33 \pm 0.39^{*} 24.75 \pm 0.42^{* *}$ \\
$\begin{array}{l}\text { K: BW } \\
\text { (\%) }\end{array}$ & $1.2 \pm 0.22$ & $0.92 \pm 0.33$ & $0.96 \pm 0.28$ & $0.85 \pm 0.30$ & $0.69 \pm 0.33^{* *} 0.66 \pm 0.314^{* *}$ \\
\hline
\end{tabular}

Route of administration: oral, values are mean \pm SEM, ${ }^{\star}$ Significant $(P<0.05)$, ${ }^{* *}$ Highly Significant $(P<0.01)$ compared to control, $\mathrm{n}=6$.

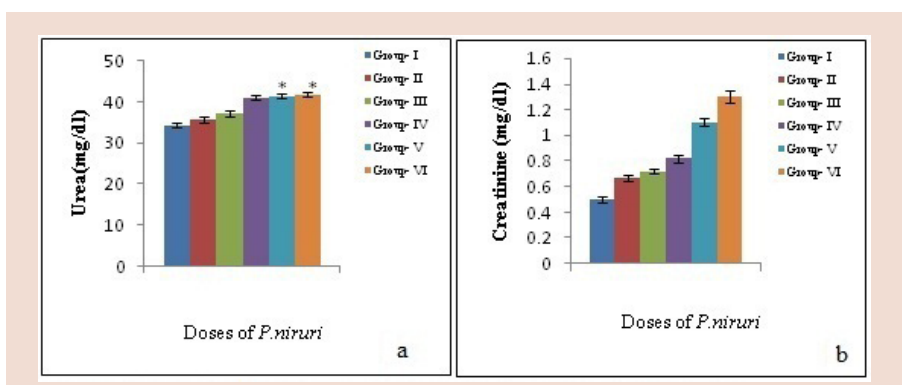

Figure 1: (a) Levels of urea $(\mathrm{mg} / \mathrm{dl})$ in different experiment groups Group-lNormal, Group-II - 500 mg/Kg w Group-III - 100 mg/Kg bw, Group-IV-2000mg/ $\mathrm{kg} \mathrm{bw}$, Group-V-2500 mg/Kg bw and Group-Vl-3000 mg/Kg bw of aqueous leaf extract of $P$. niruri treated mice. ${ }^{*} P=0.05$, compared to control value (GroupI). (b) Levels of creatinine $(\mathrm{mg} / \mathrm{dl})$ in different experimental groups Group-INormal, Group-II-500 mg/Kg bw Group-III-1000 mg/Kg bw, Group-IV-2000mg/ $\mathrm{Kg}$ bw, Group-V-2500 mg/Kg bw and Group-VI-3000 mg/Kg bw of aqueous leaf extract of $P$. niruritreated mice. ${ }^{*} P=0.05$, compared to control value (Group-I).

revealed statistically significant $(P \leq 0.05)$ increase in Group-V and Group-VI as compared to control (Group-I). There were no any marked alteration has been recorded in any groups in serum creatinine level in comparison to control group.

Light microscopic study of the cross section of kidney tissues of control Group-I revealed normal architecture of renal cells. In Group-II, Group-III and Group-IV (Figure 2b, 2c, 2d), renal cells are relatively normal, mild edema and mild congestion were observed. In Group-V (Figure 2e) congestion in renal cells were observed whereas, in Group-VI (Figure 2f) tubular edema, congestion, desquamation and degeneration were also observed.

\section{DISCUSSION}

There is growing concern about the toxicity profile of herbal plant during last decade due to the bioactive ingredients. Acute tubular ne- 


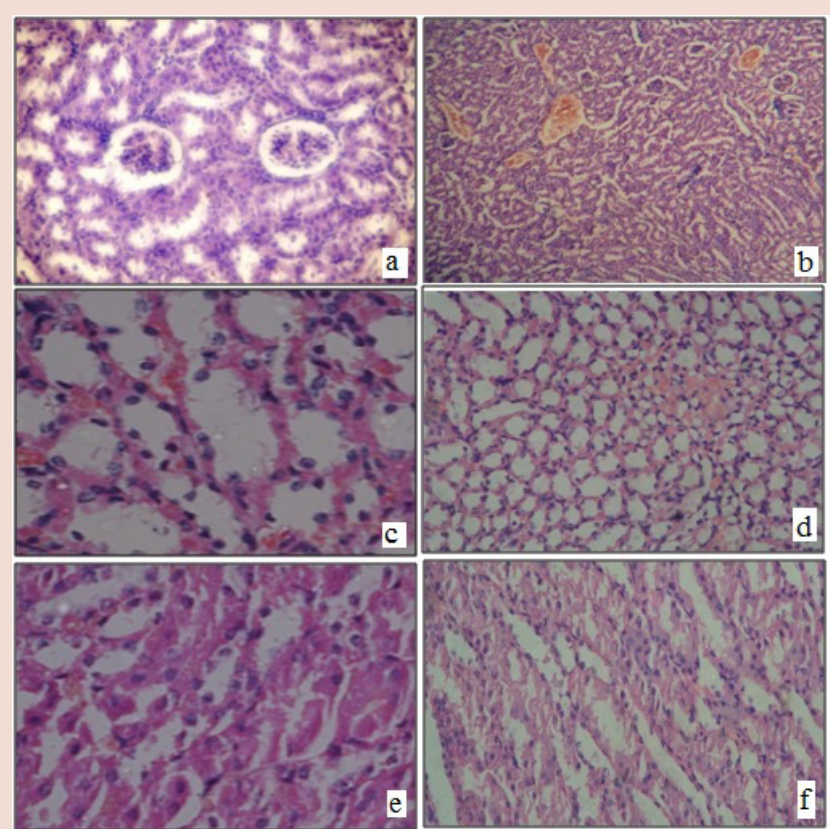

Figure 2: a: Section of control mice kidney showing normal glomeruls, proximal tubules (PT) and distal tubules (DT). b: Section of kidney of $500 \mathrm{mg} / \mathrm{Kg}$ bw of $P$. niruri treated mice (Group-II) showing mild edema in distal tubues (DT). c: Section of kidney of $1000 \mathrm{mg} / \mathrm{Kg}$ bw of $P$. niruri treated mice (Group-III) showing mild edema in tubules. $\mathbf{d}$ : Section of kidney of $2000 \mathrm{mg} / \mathrm{Kg}$ bw of $P$. niruri treated mice (Group-IV) showing mild edema and congestion in tubules. e: Section of kidney of $2500 \mathrm{mg} / \mathrm{Kg}$ bw of $P$. niruri treated mice (Group-IV) showing edema in tubules. f: Section of kidney of $3000 \mathrm{mg} / \mathrm{Kg}$ bw of $P$. niruri treated mice (GroupV) showing tubular degeneration, edema and congestion in tubules.

crosis, Acute renal failure, nephropathy, tubular necrosis, acute interstitial nephritis are serious complications resulting from the use of herbs like Pithecellobium labatum, Aristolochia fangchi, Uncaria tomentosa. ${ }^{10-14}$ Therefore, the present investigation has been conducted to understand the biochemical and histopathological alterations associated with acute oral toxicity of aqueous leaf extract of $P$. niruri.

Acute toxicity $\left(\mathrm{LD}_{50}\right)$ test gives a clue on the range of doses that could be used in subsequent toxicity for testing and estimating the therapeutic index of drugs and xenobiotics. ${ }^{10}$ In the study, the meadian lethal dose $\left(\mathrm{LD}_{50}\right)$ of the aqueous extract of P. niruri was found to be $2590.984 \mathrm{mg} /$ $\mathrm{Kg}$ bw. In female Sprague-Dawley (S-D) rats, it was more than $5000 \mathrm{mg} /$ Kg bw. ${ }^{15}$ These variations in the acute toxicity study was due to difference in route of entry, duration and frequency of exposure, age, sex, variations between different species (interspecies) and variations among members of the same species (intraspecies).$^{16}$ Body weight and organ weight are important factors to monitor the health of an individual and to analyze the toxic impact of herbal plant extracts. ${ }^{17}$ Loss in body weight is frequently the first indicator of the onset of an adverse effect. A dose, which causes $10 \%$ or more reduction in the body weight, is considered to be a toxic dose. ${ }^{7}$ Organ weights are widely accepted for the evaluation of test article-associated toxicities. ${ }^{18,19}$ Hence the decrease in body and organ weight in the present investigation at high dose of aqueous extract of P.niruri indicates its toxic potential. In the present study the decrease in body weight at higher doses in treated Group-V and Group-VI. The organ weight in relation to body weight revealed marked alteration and that was statistically significant. Various studies have been conducted to understand the toxic effect on the kidney.

Serum urea and creatinine acts as an indicators for kidney function tests as studied by Williams (1999). ${ }^{20}$ Urea is the main end product of protein catabolism. Serum urea level varies directly with protein intake and inversely with the rate of excretion. Creatinine is the waste product formed in muscle by creatinine metabolism and it is synthesized in liver, passes into circulation and taken up almost entirely by skeletal muscles. ${ }^{21}$ Increase in creatinine level may indicate the renal damage. In the present study, increased serum urea has been recorded in Group-V and Group-VI. The increased serum level may indicate renal function impairment due to adverse effect of higher doses of aquous leaf extract of P.niruri on the kidney. ${ }^{22}$ Rise in serum creatinine depends upon the extent of tubular necrosis. ${ }^{23}$ However, in the present study no any marked alteration in serum level of creatinine has been recorded. The histological alterations in tubular structure and glomeruli function lead the various architectural alteration in micro-section of the nephrocytes of aqueous leaf extract of P.niruri were observed, indicating toxicity and adverse. ${ }^{24-27}$ The toxic effect of aqueous leaf extract of $P$. niruri on kidney may be due to anyone or more of the phytochemicals present in the extract. ${ }^{17}$

\section{CONCLUSION}

These results provide evidence of toxicity profile of the aqueous leaf extracts of P.niruri at high doses. Hence, it should be ingested with caution. The acute toxicity study of $\mathrm{LD}_{50}$ determination was due to active ingredients responsible for toxic effects. Therefore, observed biochemical and histological finding supports that it is be used or administered as nephroprotective agent at lower doses or definitely used with cautions.

\section{ACKNOWLEDGEMENTS}

This study was financially supported by University Grant Commission, New Delhi, India (Project No. 35-53/2008). The authors gratefully acknowledge Mahavir Cancer Sansthan, Patna, Bihar, India for providing infrastructural facilities.

\section{ABBREVIATION USED}

LD $_{50}$ : Lethal dose, H \& E: Hematoxylin \& Eosin, PT: Proximal tubules; DT: Distal tubules.

\section{REFERENCES}

1. Mukeshwar P, Debnath M, Gupta S, Chikara SK. Phytomedicine: An ancient approach turning into future potential source of therapeutics. Journal of Pharmacognosy and phytotherapy. 2011; 3(2): 27-37.

2. Owolabi M, Coker H, Jaja S. Bioactivity of the phytoconstituents of the leaves of Persea americana. J Med Plant Res. 2010; 53(2): 239-43.

3. Nascimento GG, Locatelli J, Freitas PC, Silva GL. Antibacterial activity of plant extracts and phytochemicals on antibiotic-resistant bacteria. Brazilian journal of microbiology. 2000; 31(4): 247-56

4. LC, Etoa F, Nkegoum B, Pieme C, Dzeufiet D. Acute and subacute toxicity of Aspilia africana leaves. African Journal of Traditional, Complementary and Alternative Medicines. 2008; 4(2): 127-34.

5. Ezeonwu VU. Effects of bi-herbal ethanolic extract of phyllanthus niruri and moringa oliefera on the plasma glucose level and hematological parametersof streptozotocin-induced diabetic albino rats. 2012

6. Bagalkotkar G, Sagineedu S, Saad M, Stanslas J. Phytochemicals from Phyllanthus niruri Linn. and their pharmacological properties: a review. Journal of pharmacy and pharmacology. 2006; 58(12): 1559-70.

7. Pingale SS, Shewale SS. Acute Toxicity Study of Phyllanthus Amarus. International Journal of Pharmaceutical Sciences Review and Research. 2011; 9(1): $81-4$.

8. Nijveldt RJ, Van Nood E, Van Hoorn DE, Boelens PG, Van Norren K, Van Leeuwen PA. Flavonoids: a review of probable mechanisms of action and potential applications. The American journal of clinical nutrition. 2001; 74(4): 418-25.

9. Njoroge A, Anyango B, Dossaji S. Screening of Phyllanthus species for antimicrobial properties. 2012

10. Elvin-Lewis M. Should we be concerned about herbal remedies. Journal of ethnopharmacology. 2001; 75(2): 141-64.

11. Nortier JL, Martinez M-CM, Schmeiser HH, Arlt VM, Bieler CA, Petein M, et al Urothelial carcinoma associated with the use of a Chinese herb (Aristolochia fangchi). New England Journal of Medicine. 2000; 342(23): 1686-92. 
12. Stengel B. Chronic kidney disease and cancer: a troubling connection. JN journal of nephrology. 2010; 23(3): 253.

13. Segasothy M, Swaminathan M, Kong N, Bennett WM. Djenkol bean poisoning (djenkolism): an unusual cause of acute renal failure. American journal of kidney diseases. 1995; 25(1): 63-6.

14. Bednarova V, Bodlakova B, Pelclova D, Sulkova S. Mushroom poisoning by Cortinarius orellanus. Casopis lekaru ceskych. 1999; 138(4): 119-21.

15. Asare G, Addo P, Bugyei K, Gyan B, Adjei S, Otu-Nyarko L, et al. Acute toxicity studies of aqueous leaf extract of Phyllanthus niruri. Interdisciplinary toxicology. 2011; 4(4): 206-10.

16. Black H. Preparation of the report for a toxicology/pathology study. Handbook of Toxicologic Pathology (WM Haschek, CG Rousseaux, and MA Wallig, eds). 2002; 1: 419-33

17. Singh T, Sinha N, Singh A. Biochemical and histopathological effects on liver due to acute oral toxicity of aqueous leaf extract of Ecliptaalba on female Swiss albino mice. Indian journal of pharmacology. 2013; 45(1): 61.

18. Tanuja, Singh A, Nivedita. Nephrotoxicology effects of aqueous leaf extract of E.alba on Swiss albino mice.

19. Jothy SL, Zakaria Z, Chen Y, Lau YL, Latha LY, Sasidharan S. Acute oral toxicity of methanolic seed extract of Cassia fistula in mice. Molecules. 2011; 16(6): 5268-82.

20. Williams MH. Nutrition for health, Fitness and sport. Boston: McGraw-Hill;
1999. p. 93-113.

21. Sottas P-E, Kapke GF Leroux J-M. Adaptive bayesian approach to clinical trial renal impairment biomarker signal from urea and creatinine. International journa of biological sciences. 2013; 9(2): 156.

22. PG, Suresh P, Mishra G, Annapurna M. Pelagia Research Library. European Journal of Experimental Biology. 2011; 1(3): 236-45.

23. Solez K. Pathogenesis of acute renal failure. International review of experimental pathology. 1982; 24: 277-333.

24. Adjene JO, Nwose EU. Histological effects of chronic administration of Phyllanthus amarus on the kidney of adult Wistar rat. North American journal of medical sciences. 2010; 2(4): 193.

25. Mossalam HH, Abd-El Aty OA, Morgan EN, Youssaf SM, Mackawy AMH. Biochemical and Ultra Structure Studies of the Antioxidant Effect of Aqueous Extract of Hibiscus Sabdariffa on the Nephrotoxicity Induced by Organophosphorous Pesticide (Malathion) on the Adult Albino Rats. Journal of American Science. 2011; 7(12): 561-72

26. Solez K. Pathogenesis of acute renal failure. International review of experimental pathology. 1982; 24: 277-333.

27. Adjene JO, Nwose EU. Histological effects of chronic administration of Phyllanthus amarus on the kidney of adult Wistar rat. North American journal of medical sciences. 2010; 2(4): 193

\section{PICTORIAL ABSTRACT}

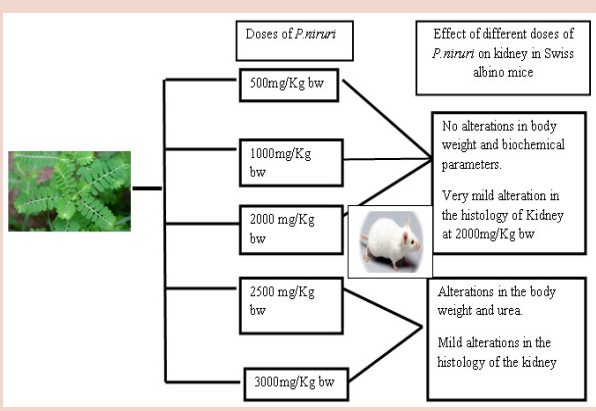

\section{SUMMARY}

- $\mathrm{LD}_{50}$ of the aqueous leaf extract of P. niruri was found to be $2590.984 \mathrm{mg} /$ $\mathrm{Kg}$ bw in Swiss albino mice.

- No significant changes in biochemical and hostological indices was observed in lower dose that is $500,1000,2000 \mathrm{mg} / \mathrm{Kg} \mathrm{bw}$.

- Histological alterations were observed at higher doses $2500 \mathrm{mg} / \mathrm{Kg}$ bw and $3000 \mathrm{mg} / \mathrm{Kg}$ bw.

- Biochemical and histological finding supports that it is be used or administered as nephroprotective agent at lower doses or definitely used with cautions.

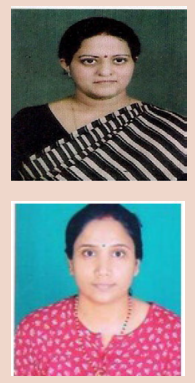

Dr. Tanuja Singh: Associate professor in T.P.S college, affliatted to Magadh university in the department of Botany. Expertise in phytochemical scrrening of herbal medicine and Effect of TCDD in environment.

Ruchi: Research scholar in B.M.D College, Bihar University. Research focus on the effect of TCDD on kidney of Swiss albino mice and it's remedies by medicinal plants. 